\title{
Livestock Contribution to Climate Change - A Review
}

\author{
Ramandeep Kaur ${ }^{1}$, Parteek Singh Dhaliwal ${ }^{2}$ and S.S. Dhindsa ${ }^{3 *}$
}

${ }^{1}$ School of Animal Biotechnology, ${ }^{2}$ Veterinary and Animal Husbandry Extension Education, ${ }^{3}$ Department of Veterinary Gynaecology and Obstetrics, School of Animal Biotechnology, Guru Angad Dev Veterinary and Animal Sciences University, Ludhiana, India-141004

*Corresponding author

\begin{tabular}{|l|}
\hline K e y w o r d s \\
Climate change, \\
Livestock, \\
Mitigation \\
strategies
\end{tabular}

\section{Introduction}

Livestock contribute 14.5 percent of the total annual anthropogenic greenhouse gas (GHG) emissions globally (Gerber et al., 2011). Livestock influence climate through land use change, feed production, animal production, manure, and processing and transport. Feed production and manure emit carbon dioxide $\left(\mathrm{CO}_{2}\right)$, nitrous oxide $\left(\mathrm{N}_{2} \mathrm{O}\right)$, and methane
$\left(\mathrm{CH}_{4}\right)$, which consequently affect climate change. Processing and transport of animal products and land use change contributes to the increase of $\mathrm{CO}_{2}$ emissions. The animal production system, which is vulnerable to climate change, is itself a large contributor to global warming through emission of methane and nitrous oxide. Mainly there are two sources of GHG emissions from livestock: (a) from the digestive process: Methane is 
produced in herbivores as a by-product of 'enteric fermentation' a digestive process by which carbohydrates is broken down by micro-organisms into simple molecules for absorption into the blood stream (b) from animal wastes: Animal wastes contain organic compounds such as carbohydrates and proteins. During the decomposition of livestock wastes under moist, oxygen free (anaerobic) environments, the anaerobic bacteria transform the carbon to methane. Animal wastes also contain nitrogen in the form of various complex compounds. The microbial processes of nitrification and denitrification forms nitrous oxide, which is emitted to the atmosphere.

The GHG emissions from the agriculture sector account for about 25.5 percent of total global radioactive forcing and over 60 percent of anthropogenic sources (FAO, 2009). Animal agriculture is responsible for 18 percent of greenhouse gas (GHG) emissions $\left(9 \% \mathrm{CO}_{2}, 37 \%\right.$ methane and $\left.65 \% \mathrm{~N}_{2} \mathrm{O}\right)(\mathrm{FAO}$, 2006). Ruminants (cattle, sheep and goats) account for a large share of total livestock emissions, because they are less efficient in converting forage into useful products than monogastrics (pigs and poultry). GHG emissions includes methane $\mathrm{CH}_{4}$ emission from enteric fermentation and manure management, nitrous oxide $\mathrm{N}_{2} \mathrm{O}$ emission from animal manure and $\mathrm{CO}_{2}$ emission from land-use change caused by demand for feed grains, grazing land and agricultural energy and as much as 37 percent of anthropogenic methane emission from the agriculture sector (FAO, 2006).

\section{Enteric fermentation}

Emission of $\mathrm{CH}_{4}$ is responsible for nearly as much radiative forcing as all other non- $\mathrm{CO}_{2}$ GHGs combined (Beauchemin and McGinn, 2005). Recent estimation of livestock methane production using IPCC methodology indicates that the total methane emitted due to enteric fermentation and manure of 485 million heads of livestock was $9.37 \mathrm{Tg} /$ annum for the year 2003. The other livestock with minor population consisting only 2 percent $(0.15 \mathrm{Tg})$ of total emission from livestock sector. The ruminants, both small and large, were the main contributors (98\%) to the enteric methane emission in India. In India more than 90 percent of the total methane emission from enteric fermentation is being contributed by the large ruminants (cattle and buffalo) and rest from small ruminants and others (Swamy and Bhattacharya, 2006). The major contributors to methane emission were indigenous, crossbred cattle, buffalo and sheep \& goat accounting 40, 8, 40 and 10 percent, respectively. Initial microbial breakdown (essential in ruminant digestion) occurs in the rumen, or large fore-stomach, where microbial fermentation converts fibrous feed into products digested and utilized by the animal (Boadi et al., 2004; USDA, 2004). Rumination promotes digestion of cellulose and hemicelluloses through hydrolysis of polysaccharides by microbes and protozoa, which is followed by microbial fermentation generating $\mathrm{H}_{2}$ and $\mathrm{CO}_{2}$. Methane is produced as a by-product of enteric fermentation and carbohydrate digestion and is expelled through the mouth via eructation (Monteny et al., 2001). Amount of feed consumed and its digestibility are two important factors, which determine the total methane production. The livestock characteristics (age, weight and species), health and living conditions influence the energy requirement. Higher methane production results from higher energy requirement and feed intake. On average Indian cattle produces about 35 $\mathrm{kg}$ /annum methane as compared to 95 $\mathrm{kg} / \mathrm{annum}$ for dairy cows in Germany (Crutzen et al., 1986; Sirohi and Michaelowa,2007) due lower energy requirement. The lowest annual methane 
production for dairy (180 kg/herd) and nondairy cattle was reported in Indian subcontinent (Sharma et al.,2006) while comparing with north America, western Europe, eastern Europe, Oceania, Africa and middle east. Lactating animals comprising of buffaloes and cattle contributed $3.42 \mathrm{Tg}$ with a major share of $2.04 \mathrm{Tg}$ from lactating buffaloes (Upadhyay et al., 2009). The contribution of milch buffaloes was 59.6, crossbred cows 11.4 and indigenous cows 28.9 percent to the total emissions from dairy animals (Upadhyay et al., 2009). Singhal et al., (2005) reported total emission of methane from Indian livestock as 10.08 MT considering different categories of ruminants and type of feed resources available in different zones of the country. Although goats are the dominant livestock with a population share of 33.1 percent, but contribution to the $\mathrm{CH}_{4}$ emission is only $0.14 \mathrm{Tg} /$ year or 4.5 percent by this species.

\section{Livestock manure management}

Livestock manure is primarily composed of organic material and water. Under anaerobic conditions, the organic material in the livestock manure is decomposed by anaerobic and facultative bacteria resulting into formation of $\mathrm{CH}_{4}, \mathrm{CO}_{2}$ and stabilized organic material. Livestock manure management is also a significant source of $\mathrm{CH} 4$ emission (Swamy and Bhattacharya, 2006). The management of animal manure can produce anthropogenic $\mathrm{CH}_{4} \quad$ via anaerobic decomposition of manure and $\mathrm{N} 2 \mathrm{O}$ via nitrification and denitrification of organic $\mathrm{N}$ in animal manure and urine (Bouwman, 1996). Typically, when livestock manure is stored or treated in lagoons, ponds, or tanks (i.e., anaerobic conditions), $\mathrm{CH}_{4}$ emissions are produced in higher amounts than when manure is handled as a solid (e.g., stacks or dry lot corrals), or deposited on pasture where aerobic decomposition occurs thereby reducing $\mathrm{CH}_{4}$ emissions. Both $\mathrm{CH}_{4}$ and $\mathrm{N}_{2} \mathrm{O}$ production are influenced by multiple variables including climate, soil conditions, substrate availability, and land management practices (Chen et al., 2008). The total global $\mathrm{CH}_{4}$ emissions from livestock manure management have been estimated as 9.3 Tg/year, of which the developed countries contribute about 52 percent. The different manure management practices in India, as compared to the western countries, lead to much lower methane emissions from manure. Cattle and buffalo manure is extensively used in the country as fuel and is largely managed in dry systems. The emissions for India are estimated to be $1.27 \mathrm{Tg}$ in the year 1994 (Singhal and MadhuMohini 2002). India's contribution to nitrous oxide emissions from manure management in 1990 is estimated to be $0.017 \mathrm{Tg} /$ year, which is projected to increase to $0.022 \mathrm{Tg}$ by 2020 .

\section{Adaptation and Mitigation Strategies}

Adaptation strategies can improve the resilience of crop and livestock productivity to climate change (USDA, 2013). Mitigation measures could significantly reduce the impact of livestock on climate change (Dickie et al., 2014). Adaptation and mitigation can make significant impacts if they become part of national and regional policies (FAO, 2009).

Adaptation measures involve production and management system modifications, breeding strategies, institutional and policy changes, science and technology advances, and changing farmers' perception and adaptive capacity (IFAD, 2010; Rowlinson et al., 2008; USDA, 2013). Research is needed on assessments for implementing these adaptation measures and tailoring them based on location and livestock system. This could be accomplished with GIS and remote sensing technologies applicable at broad and local scales (Thornton et al., 2009). 


\section{Livestock production and management} systems

An adaptation such as the modification of production and management systems involves diversification of livestock animals and crops, integration of livestock systems with forestry and crop production, and changing the timing and locations of farm operations (IFAD, 2010). Diversification of livestock and crop varieties can increase drought and heat wave tolerance, and may increase livestock production when animals are exposed to temperature and precipitation stresses. In addition, this diversity of crops and livestock animals is effective in fighting against climate change-related diseases and pest outbreaks (Batima et al., 2005; IFAD, 2010; Kurukulasuriya and Rosenthal, 2003).

Agroforestry as a land management approach can help maintain the balance between agricultural production, environmental protection and carbon sequestration to offset emissions from the sector. Agroforestry may increase productivity and improve quality of air, soil, and water, biodiversity, pests and diseases, and improves nutrient cycling (Jose, 2009; Smith et al., 2012).

Changes in mixed crop-livestock systems are an adaptation measure that could improve food security (Herrero et al., 2010; Wani et al., 2009). This type of agricultural system is already in practice in two-thirds of world, producing more than half of the milk, meat, and crops such as cereal, rice and sorghum. Changes in mixed crop-livestock systems can improve efficiency by producing more food on less land using fewer resources, such as water (Steinfeld et al., 2006).

Improving feeding practices as an adaptation measure could indirectly improve the efficiency of livestock production (Havlík et al., 2013). Some of the suggested feeding practices include, modification of diets composition, changing feeding time and/or frequency, incorporating agroforestry species in the animal diet and conservation of feed for different agro-ecological zones (Renaudeau et $a l ., 2012)$. These practices can reduce the risk from climate change by promoting higher intake or compensating low feed consumption, reducing excessive heat load (Renaudeau et al., 2012).

Shifting locations of livestock and crop production could reduce soil erosion and improve moisture and nutrient retention (Kurukulasuriya and Rosenthal, 2003). Another adaptive measure could be adjusting crop rotations and changing timing of management operations (e.g. grazing, planting, spraying, irrigating). This measure can be adapted to changes in duration of growing seasons, heat waves and precipitation variability.

\section{Breeding strategies}

Changes in breeding strategies can help animals increase their tolerance to heat stress and diseases and improve their reproduction and growth development (Rowlinson, 2008). Therefore, the challenge is in increasing livestock production while maintaining the valuable adaptations offered by breeding strategies, all of which will require additional research (Thornton et al., 2009). In addition, policy measures that improve adaptive capacity by facilitating implementation of adaptation strategies will be crucial (USDA, 2013). For example, developing international gene banks could improve breeding programs and serve as an insurance policy, such as has been done for plants with the In-Trust plant collections in the CGIAR gene banks (Thornton et al., 2009). This would be a major breakthrough that requires significant investment and international collaboration to succeed. 


\section{Adaptation capability of farmer}

One of the limiting factors for these changes to succeed is the disposition and capability of farmers to recognize the problem and adopt climate change adaptation and mitigation measures. Because of this, it is important to collect information about farmers' perceptions to mitigation and adaptation measures. One approach for collecting information about farmers' perceptions that has been used for mitigation and adaptation research is qualitative; using open-ended survey questions or group discussion at workshops to understand individual and group opinions (Barnes et al., 2013). By understanding farmers' perceptions and including them in rural policy development, there is a greater chance of accomplishing food security and environmental conservation objectives (Oliver et al., 2012).

\section{Mitigation strategies}

Agriculture was responsible for 10-12 percent of total global non- $\mathrm{CO}_{2}$ greenhouse gas (GHG) emissions in 2005, but emissions of $\mathrm{CH}_{4}$ and $\mathrm{N}_{2} \mathrm{O}$ increased globally by nearly 17 percent from 1990 to 2005, with both gases contributing equally to the increase (Smith et al., 2007). Enteric $\mathrm{CH}_{4}$ fermentation accounted for about 32 percent of total non$\mathrm{CO}_{2}$ emissions from agriculture in 2005 (Smith et al., 2007). If $\mathrm{CH}_{4}$ emissions grow in direct proportion to projected increases in livestock numbers, then global $\mathrm{CH}_{4}$ emissions from livestock production are expected to increase 60 percent by 2030 (FAO, 2009). Given the contribution of $\mathrm{CH}_{4}$ to global GHG production, there have been several recent reviews of mitigation strategies to reduce enteric $\mathrm{CH}_{4}$ emissions from livestock (Eckard et al., 2010). Reducing the increase of GHG emissions from agriculture, especially livestock production should therefore be a top priority, because it could curb warming fairly rapidly (Sejian et al., 2010). Several options have been considered for mitigating methane production and emitting in atmosphere by the livestock. All approaches points towards either reduction of methane production per animal or reduction per unit of animal product (Johnson et al., 2002). Methane has relatively short life (10-12 years) in the atmosphere as compared to other GHGs, for example $\mathrm{CO}_{2}$ has 120 years and therefore strategies to reduce the methane in atmosphere offer effective and practical means to slow global warming (Turnbull and Charme, 2001).

\section{Control of livestock population}

Increase in animal productivity can be achieved through improvements in animal genetics, feeding, reproduction, health, and overall management of the animal operation. In the Netherlands, with increase in milk production per cow from $6,270 \mathrm{~kg}$ in base year 1990 to $8.350 \mathrm{~kg}$ in 2008, $\mathrm{CH} 4$ production was decreased from 17.6 to $15.4 \mathrm{~g} / \mathrm{kg}$ FPCM, respectively (Bannink et al., 2011). Blummel et al., (2009) estimated that increasing milk yield per animal in India from the national average of $3.6 \mathrm{~kg}$ to $9.0 \mathrm{~kg} / \mathrm{day}$ was possible using currently available feed resources, and this would potentially reduce $\mathrm{CH}_{4}$ production in the country from 2.29 to $1.38 \mathrm{Tg} / \mathrm{yr}$.

Sheep population has been reduced from 57.9 million in 1990 to 45.2 million in 2000, while dairy cattle and beef cattle population have increased slightly. The net outcome was a decline in ruminant $\mathrm{CH}_{4}$ emission from 1.45 to $1.31 \mathrm{Tg}$ /year from 1990 to 2000 (Sejian et al., 2011).

\section{Optimal animal nutrition}

Dietary manipulation through increased green fodder decreased methane production by 5.7 percent (Singhal and MadhuMohini 2002). 
Ruminant production systems based on concentrate feeds are reportedly more efficient from the animal perspective and emit less GHG per unit of product (Pelletier et al., 2010).Increasing the concentrate in the diet of animals reduced methane by 15-32 percent depending on the ratio of concentrate in diet (Singhal and MadhuMohini 1999). Bell et al., (2011) demonstrated that improvements in feed efficiency and milk production can significantly reduce GHG emissions and land use of the dairy herd. However, selection for high milk production and decreased productive life, increased death rate, and decline in fertility need to be avoided (Norman et al., 2009). Organic dairy production systems have generally higher GHG emission than conventional dairy systems (Heller and Keoleian, 2011). Field experiments in India showed that dietary manipulation through increased green fodder decreased methane production by 5.7 percent (Singhal and MadhuMohini 2002).

\section{Feeding management}

Composition of diet has the effect on the rumen microbial ecosystem so any manipulation in the diet by means of forage, concentrate and their components results in change in the microbial community and may decrease or inhibit activity of methanogenic bacteria. There are several strategies which can be used to reduce methane production from livestock.

Methane Inhibitors tested in vivo were bromo-chloromethane (BCM), 2-bromoethenesulfonate (BES), chloroform and cyclodextrin reduced methane production by up to 50 percent in cattle and small ruminants (Knight et al.,2011)

Ionophore antibiotics such as monensin are known to decrease methane production (typically used to improve animal efficiency for production) (Beauchemin et al.,2008).

Feeding of nitrate can also decrease enteric methane production by up to 50 percent (Hulshof et al., 2012).

In conclusion, all these strategies call for formulation of long-term policies at government level and significant investment in the livestock production and processing industry; which may help in improvement and boost of livestock production.

\section{References}

Bannink, A., Van Schijndel, M.W. and Dijkstra, J. 2011. A model of enteric fermentation in dairy cows to estimate methane emission for the Dutch National Inventory Report using the IPCC Tier 3 approach. Anim. Feed Sci. Tech. 166-167: 603-618.

Barnes, A.P., 2013. Heterogeneity in climate change risk perception amongst dairy farmers: a latent class clustering analysis. Appl. Geogr.. 41: 105-115.

Batima, P., Bat, B., Tserendash, L., Bayarbaatar, S., Shiirev-Adya, S., Tuvaansuren, G., Natsagdorj, L.andChuluun, T. 2005. Adaptation to Climate Change, Vol. 90. ADMON Publishing, Ulaanbaatar.

Beauchemin, K.A. and Mcginn, S.M. 2005. Methane emissions from feedlot cattle fed barley or corn diets. J. of Anim. Sci. 83: 653-661.

Beauchemin K.A., Kreuzer M., O’Mara F. and McAllister T.A. 2008. Nutritional management for enteric methane abatement: a review. Aust. J. Exp. Agric. 48: 21-27.

Bell, M.J., Wall, E., Russell, G., Simm, G. and Stott, A.W. 2011. The effect of improving cow productivity, fertility, and longevity on the global warming 
potential of dairy systems. J. Dairy Sci. 94: 3662-3678.

Blümmel, M., Anandan, S. and Prasad, C.S. 2009. Potential and Limitations of byproduct Based Feeding Systems to Mitigate Greenhouse Gases for Improved Livestock Productivity. In Proceedings of the 13th Biennial Conference of Animal Nutrition Society of India, National Institute of Animal Nutrition and Physiology,Bangalore, India.pp. 6874.

Boadi, D, Benchaar, C., Chiquette, J. and Masse, D. 2004. Mitigation strategies to reduce enteric methane emissions from dairy cows: Update review. Canadian J. Anim. Sci. 84: 319-335.

Bouwman, A. 1996. Direct emissions of nitrous oxide from agricultural soils. Nutr.Cycl.Agroecosys. 46: 53-70.

Chen, D., Li, Y., Grace, P. and Mosier, A. R. 2008. N2O emissions from agricultural lands: A synthesis of simulation approaches. Plant Soil.pp. 309.

Crutzen, P.J., Aselmann, I. and Seiler, W. 1986. Methane production by domestic animals, wild ruminants, other herbivorous fauna and humans. Tellus. 38B: 271-284.

Dickie, A., Streck, C., Roe, S., Zurek, M., Haupt, F.andDolginow, A. 2014. Strategies for mitigating climate change in agriculture: Abridged report. Climate focus and california environmental associates, prefaded with the support of the climate and land use Alliance.

Eckard, R.J., Grainger, C. and de Klein, C.A.M. 2010. Options for the abatement of methane and nitrous oxide from ruminant production: A review. Livest. Sci. 130: 47-56.

FAO, 2006. Steinfeld, H., Gerber, P., Wassenaar, T., Castel V,Rosales,
M.and de Haan, C. (eds.) Livestock's long shadow. Environmental issues and options. http://fao.org/docrep.

FAO, 2009. The state of food and agriculture: Livestock in the balance. Food and Agriculture Organization of the United Nations.

Gerber, P., Vellinga, T., Opio, C. and Steinfeld, H. 2011. Productivity gains and greenhouse gas emissions intensity in dairy systems. Livest. Sci. 139: 100-108.

Havlík, P., Valin, H., Mosnier, A., Obersteiner, M., Baker, J.S., Herrero, M., Rufino, M.C.andSchmid, E. 2013. Crop productivity and the global livestock sector: Implications for land use change and greenhouse gas emissions. Am. J. Agric. Econ. 95: 442-448.

Heller, M.C. and Keoleian, G.A. 2011. Life cycle energy and greenhouse gas analysis of a large-scale vertically integrated organic dairy in the United States. Environ. Sci. Technol. 45: 1903-1910.

Herrero, M., Thornton, P.K., Notenbaert, A., Msangi, S., Wood, S., Kruska, R., Dixon, J., Bossio, D., van de Steeg, J., Ade Freeman, H., Li, X.andParthasarathyRao, P. 2012. Drivers of Change in Crop-Livestock Systems and Their Potential Impacts on Agro-Ecosystems Services and Human Wellbeing to 2030: A Study Commissioned by the CGIAR Systemwide Livestock Programme. International Livestock Research Institute, Nairobi, Kenya.

Hulshof, R.B.A., Berndt, A., Gerrits, W.J.J., Dijkstra, J., Van Zijderveld, S.M., Newbold, J.R. and Perdok, H.B. 2012. Dietary nitrate supplementation reduces methane emission in beef cattle fed sugarcane based diets. J. Anim. Sci. 90:2317-2323. 
IFAD (International Fund for Agricultural Development). 2010. Livestock and climate change.

Johnson, D.E., PhetteplaceH.W. and Seidl, A. F. 2002. Methane, nitrous oxide and carbon dioxide emissions from ruminant livestock production systems. In: Takahashi, J. and B.A. Young (Eds.), GHGes and animal agriculture. Proceeding of the 1st International Conference on GHGes and Animal Agriculture, Obihiro, Japan, November 2001. pp: 77-85.

Jose, S. 2009. Agroforestry for ecosystem services and environmental benefits: an overview. Agrofor. Syst. 76: 1-10.

Knight, T., Ronimus, R.S., Dey, D., Tootill, C., Naylor, G., Evans, P., Molano, G., Smith, A., Tavendale, M., PinaresPatino, C.S. and Clark, H. 2011. Chloroform decreases rumen methanogenesis and methanogen populations without altering rumen function in cattle. Anim. Feed Sci. Technol. 166: 101-112.

Kurukulasuriya, P. and Rosenthal, S. 2003. Climate change and agriculture: a review of impacts and adaptations. Climate Change Series, Paper No. 91, World Bank, Washington DC.

Monteny, G. J., Groenestein, C. M. and Hilhorst, M. A. 2001. Interactions and coupling between emissions of methane and nitrous oxide from animal husbandry. Nutr.Cycl.Agroecosys.60: 123.

Norman, H.D., Wright, J.R., Hubbard, S.M., Miller, R.H. and Hutchison, J.L. 2009. Reproductive status of Holstein and Jersey cows in the United States. J. Dairy Sci. 92: 3517-3528.

Oliver, D.M., Fish, R.D., Winter, M., Hodgson, C.J., Heathwaite, A.L.and Chadwick, D.R. 2012. Valuing local knowledge as a source of expert data: farmer engagement and the design of decision support systems. Environ. Modell. Software. 36: 76-85.

Renaudeau, D., Collin, A., Yahav, S., De Basilio, V., Gourdine, J.L.and Collier, R.J. 2012. Adaptation to hot climate and strategies to alleviate heat stress in livestock production. Animal. 6 (05): 707-728.

Rowlinson, P., Steele, M.andNefzaoui, A. 2008. Livestock and global climate change: Adaptation I and II. In: Rowlinson, P., Steel, M., Nefzaoui, A. (Eds.), Livestock and Global Climate Change Conference Proceeding. Cambridge University Press, Tunisia. pp. 56-85.

Sejian, V., Lal, R., Lakritz,J.and Ezeji, T. 2010. Measurement and prediction of enteric methane emission. Int. J. Biomateorol. DOI: 10.1007/s00484010-0356-7.

Sejian, V., Kumar, K., Sharma, K.C. and Naqvi, S.M.K. 2011. Climate change and livestock production: Concept of multiple stresses and its significance. In: NAIP Sponsored National Training manual on "Carbon sequestration, carbon trading and climate change".

Sharma, S., Bhattacharya,A. and Garg, A.2006. Greenhouse gas emission from India: A perspective. Curr. Sci. 90(3): 326-333.

Singhal K. K. and MadhuMohini. 2002. Uncertainty reduction in methane and nitrous oxide gases emission from livestock in India. Project report, Dairy Cattle Nutrition Division, National Dairy Research Institute,Karnal, India. pp 62.

Singhal, K.K., Mohini, M., JhaA.K. and Gupta, P.K. 2005. Methane emission estimates from enteric fermentation in Indian livestock: Dry matter intake approach. Curr. Sci. 88(1): 119-127.

Sirohi, S. and Michaelowa, A.2007. Sufferer and cause: Indian livestock and 
climate change. Climatic Change. 85:285-298.

Smith, K., Cumby, T., Lapworth, J., Misselbrook, T. and Williams, A. 2007. Natural crusting of slurry storage as an abatement measure for ammonia emissions on dairy farms. Biosyst. Eng. 97: 464-471.

Smith, J.P., Pearce, B.D.and Wolfe, M.S. 2012. Reconciling productivity with protection of the environment: is temperate agroforestry the answer? Renewable Agric. Food Syst. 28 (1): 80-92.

Steinfeld, H., Gerber, P., Wassenaar, T., Castel, V., Rosales, M. and de Haan, C. 2006. Livestock's Long Shadow: Environmental Issues and Options. Rome: Food and Agriculture Organization of the United Nations.

Swamy, M. and Bhattacharya, S.2006. Budgeting anthropogenic greenhouse gas emission from Indian livestock using country-specific emission coefficients. Curr. Sci. 91(10): 13401353.

Thornton, P., Van de Steeg., J., Notenbaert, M.H. and Herrero, M. 2009. The impacts of climate change on livestock and livestock systems in developing countries: A review of what we know and what we need to know. Agri. Systems. 101: 113-127.

Turnbull, G. and Charme, B.D., 2001. Methane Emissions-Reductions from Ruminants, Market View, Annual Spring Meeting, Phoenix, Arizona.

Upadhaya, R. C., Ashutosh, A. K., Gupta, S. K.,Gupta, S.V.,Singh,S.V. and Nikita, R. 2009. Inventory of methane emission from livestock in India. In, Global climate change and Indian agriculture.Case studies from the ICAR Network project. P.K. Aggarwal (Ed), ICAR, New Delhi. pp $117-122$

USDA (United States Department of Agriculture), 2013. Climate Change and Agriculture in the United States: Effects and Adaptation. USDA technical bulletin, Washington,DC.http://www.usda.gov/ oce/climate change/effects 2012/CC \%20and\%20Agriculture\%20Report $\%$ 20\%2802-04-2013\%29b.pdf.

Wani, S.P., Rockstrom, J.andOweis, T. 2009. Rainfed Agriculture: Unlocking the Potential. CAB International, Wallingford, UK.

\section{How to cite this article:}

Ramandeep Kaur, Parteek Singh Dhaliwal and Dhindsa, S.S. 2019. Livestock Contribution to Climate Change - A Review. Int.J.Curr.Microbiol.App.Sci. 8(09): 1099-1107. doi: https://doi.org/10.20546/ijcmas.2019.809.127 